\title{
Effectiveness and safety of SARS-CoV-2 vaccine in real-world studies: a systematic review and meta-analysis
}

Qiao Liu ${ }^{1 \dagger}$, Chenyuan Qin ${ }^{1,2+}$, Min Liu $^{1 *}$ and Jue Liu ${ }^{1,2^{*}} \mathbb{D}$

\begin{abstract}
Background: To date, coronavirus disease 2019 (COVID-19) becomes increasingly fierce due to the emergence of variants. Rapid herd immunity through vaccination is needed to block the mutation and prevent the emergence of variants that can completely escape the immune surveillance. We aimed to systematically evaluate the effectiveness and safety of COVID-19 vaccines in the real world and to establish a reliable evidence-based basis for the actual protective effect of the COVID-19 vaccines, especially in the ensuing waves of infections dominated by variants.

Methods: We searched PubMed, Embase and Web of Science from inception to July 22, 2021. Observational studies that examined the effectiveness and safety of SARS-CoV-2 vaccines among people vaccinated were included. Random-effects or fixed-effects models were used to estimate the pooled vaccine effectiveness (VE) and incidence rate of adverse events after vaccination, and their 95\% confidence intervals (CI).

Results: A total of 58 studies (32 studies for vaccine effectiveness and 26 studies for vaccine safety) were included. A single dose of vaccines was $41 \%$ (95\% Cl: 28-54\%) effective at preventing SARS-CoV-2 infections, 52\% (31-73\%) for symptomatic COVID-19, 66\% (50-81\%) for hospitalization, 45\% (42-49\%) for Intensive Care Unit (ICU) admissions, and 53\% (15-91\%) for COVID-19-related death; and two doses were 85\% (81-89\%) effective at preventing SARSCoV-2 infections, 97\% (97-98\%) for symptomatic COVID-19, 93\% (89-96\%) for hospitalization, 96\% (93-98\%) for ICU admissions, and 95\% (92-98\%) effective for COVID-19-related death, respectively. The pooled VE was 85\% (80-91\%) for the prevention of Alpha variant of SARS-CoV-2 infections, 75\% (71-79\%) for the Beta variant, 54\% (35-74\%) for the Gamma variant, and 74\% (62-85\%) for the Delta variant. The overall pooled incidence rate was 1.5\% (1.4-1.6\%) for adverse events, $0.4(0.2-0.5)$ per 10000 for severe adverse events, and $0.1(0.1-0.2)$ per 10000 for death after vaccination.
\end{abstract}

Conclusions: SARS-CoV-2 vaccines have reassuring safety and could effectively reduce the death, severe cases, symptomatic cases, and infections resulting from SARS-CoV-2 across the world. In the context of global pandemic and the continuous emergence of SARS-CoV-2 variants, accelerating vaccination and improving vaccination coverage is still the most important and urgent matter, and it is also the final means to end the pandemic.

Keywords: SARS-CoV-2, Vaccine, Effectiveness, Safety, Meta-analysis

\footnotetext{
*Correspondence: liumin@bjmu.edu.cn; jueliu@bjmu.edu.cn

${ }^{\dagger}$ Qiao Liu and Chenyuan Qin are joint first authors

${ }^{1}$ Department of Epidemiology and Biostatistics, School of Public Health,

Peking University, Beijing 100191, China

Full list of author information is available at the end of the article
}

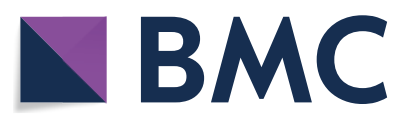

(c) The Author(s) 2021. Open Access This article is licensed under a Creative Commons Attribution 4.0 International License, which permits use, sharing, adaptation, distribution and reproduction in any medium or format, as long as you give appropriate credit to the original author(s) and the source, provide a link to the Creative Commons licence, and indicate if changes were made. The images or other third party material in this article are included in the article's Creative Commons licence, unless indicated otherwise in a credit line to the material. If material is not included in the article's Creative Commons licence and your intended use is not permitted by statutory regulation or exceeds the permitted use, you will need to obtain permission directly from the copyright holder. To view a copy of this licence, visit http://creativecommons.org/licenses/by/4.0/. The Creative Commons Public Domain Dedication waiver (http://creativeco mmons.org/publicdomain/zero/1.0/) applies to the data made available in this article, unless otherwise stated in a credit line to the data. 


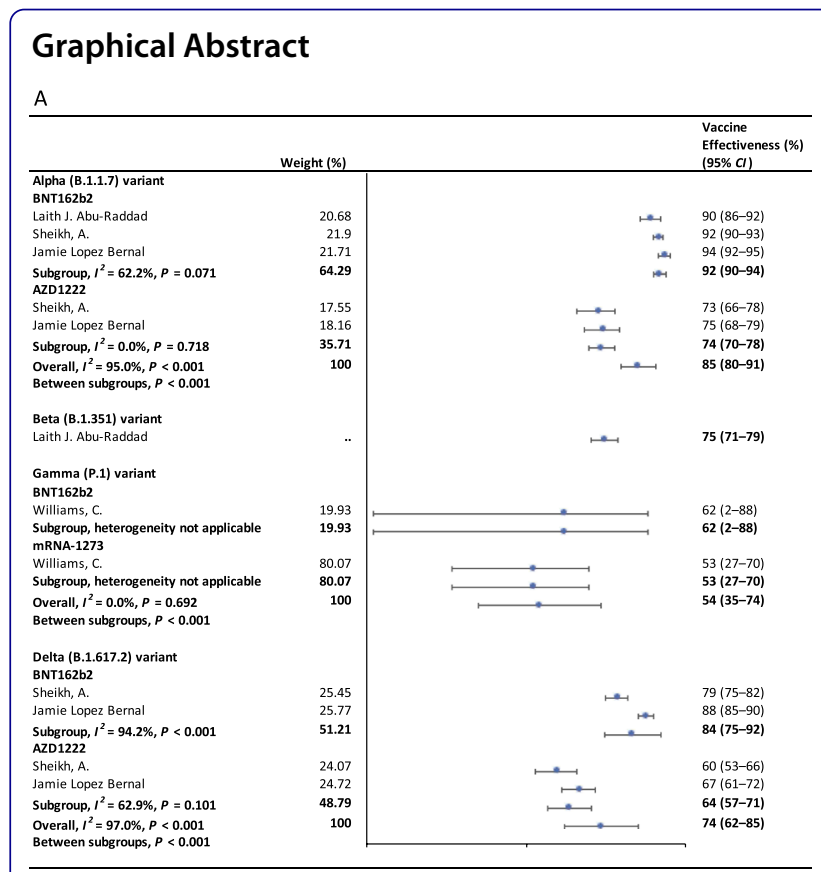

B

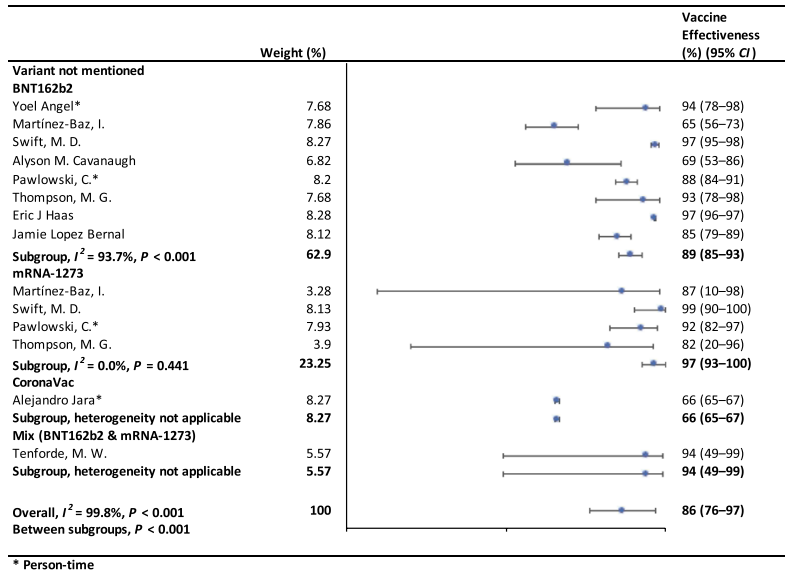

\section{Background}

Since its outbreak, coronavirus disease 2019 (COVID-19) has spread rapidly, with a sharp rise in the accumulative number of infections worldwide. As of August 8, 2021, COVID-19 has already killed more than 4.2 million people and more than 203 million people were infected [1]. Given its alarming-spreading speed and the high cost of completely relying on non-pharmaceutical measures, we urgently need safe and effective vaccines to cover susceptible populations and restore people's lives into the original [2].

According to global statistics, as of August 2, 2021, there are 326 candidate vaccines, 103 of which are in clinical trials, and 19 vaccines have been put into normal use, including 8 inactivated vaccines and 5 protein subunit vaccines, 2 RNA vaccines, as well as 4 non-replicating viral vector vaccines [3]. Our World in Data simultaneously reported that $27.3 \%$ of the world population has received at least one dose of a COVID-19 vaccine, and $13.8 \%$ is fully vaccinated [4].

To date, COVID-19 become increasingly fierce due to the emergence of variants [5-7]. Rapid herd immunity through vaccination is needed to block the mutation and prevent the emergence of variants that can completely escape the immune surveillance $[6,8]$. Several reviews systematically evaluated the effectiveness and/or safety of the three mainstream vaccines on the market (inactivated virus vaccines, RNA vaccines and viral vector vaccines) based on random clinical trials (RCT) yet [9-13].
In general, RNA vaccines are the most effective, followed by viral vector vaccines and inactivated virus vaccines [10-13]. The current safety of COVID-19 vaccines is acceptable for mass vaccination, but long-term monitoring of vaccine safety is needed, especially in older people with underlying conditions [9-13]. Inactivated vaccines had the lowest incidence of adverse events and the safety comparisons between mRNA vaccines and viral vectors were controversial $[9,10]$.

RCTs usually conduct under a very demanding research circumstance, and tend to be highly consistent and limited in terms of population characteristics and experimental conditions. Actually, real-world studies differ significantly from RCTs in terms of study conditions and mass vaccination in real world requires taking into account factors, which are far more complex, such as widely heterogeneous populations, vaccine supply, willingness, medical accessibility, etc. Therefore, the real safety and effectiveness of vaccines turn out to be a major concern of international community. The results of a mass vaccination of CoronaVac in Chile demonstrated a protective effectiveness of $65.9 \%$ against the onset of COVID-19 after complete vaccination procedures [14], while the outcomes of phase 3 trials in Brazil and Turkey were $50.7 \%$ and $91.3 \%$, reported on Sinovac's website [14]. As for the Delta variant, the British claimed $88 \%$ protection after two doses of BNT162b2, compared with $67 \%$ for AZD1222 [15]. What is surprising is that the protection of BNT162b2 against infection in Israel is 
only $39 \%$ [16]. Several studies reported the effectiveness and safety of the COVID-19 vaccine in the real world recently, but the results remain controversial [17-20]. A comprehensive meta-analysis based upon the real-world studies is still in an urgent demand, especially for evaluating the effect of vaccines on variation strains. In the present study, we aimed to systematically evaluate the effectiveness and safety of the COVID-19 vaccine in the real world and to establish a reliable evidence-based basis for the actual protective effect of the COVID-19 vaccines, especially in the ensuing waves of infections dominated by variants.

\section{Methods}

\section{Search strategy and selection criteria}

Our methods were described in detail in our published protocol [PROSPERO (Prospective register of systematic reviews) registration, CRD42021267110]. We searched eligible studies published by 22 July 2021, from three databases including PubMed, Embase and Web of Science by the following search terms: (effectiveness OR safety) AND (COVID-19 OR coronavirus OR SARSCoV-2) AND (vaccine OR vaccination). We used EndNoteX9.0 (Thomson ResearchSoft, Stanford, USA) to manage records, screen and exclude duplicates. This study was strictly performed according to the Preferred Reporting Items for Systematic Reviews and Meta-Analyses (PRISMA).

We included observational studies that examined the effectiveness and safety of severe acute respiratory syndrome coronavirus 2 (SARS-CoV-2) vaccines among people vaccinated with SARS-CoV-2 vaccines. The following studies were excluded: (1) irrelevant to the subject of the meta-analysis, such as studies that did not use SARS-CoV-2 vaccination as the exposure; (2) insufficient data to calculate the rate for the prevention of COVID19 , the prevention of hospitalization, the prevention of admission to the ICU, the prevention of COVID-19-related death, or adverse events after vaccination; (3) duplicate studies or overlapping participants; (4) RCT studies, reviews, editorials, conference papers, case reports or animal experiments; and (5) studies that did not clarify the identification of COVID-19.

Studies were identified by two investigators (LQ and QCY) independently following the criteria above, while discrepancies reconciled by a third investigator (LJ).

\section{Data extraction and quality assessment}

The primary outcome was the effectiveness of SARSCoV-2 vaccines. The following data were extracted independently by two investigators (LQ and QCY) from the selected studies: (1) basic information of the studies, including first author, publication year and study design; (2) characteristics of the study population, including sample sizes, age groups, setting or locations; (3) kinds of the SARS-CoV-2 vaccines; (4) outcomes for the effectiveness of SARS-CoV-2 vaccines: the number of laboratory-confirmed COVID-19, hospitalization for COVID-19, admission to the ICU for COVID-19, and COVID-19-related death; and (5) outcomes for the safety of SARS-CoV-2 vaccines: the number of adverse events after vaccination.

We evaluated the risk of bias using the NewcastleOttawa quality assessment scale for cohort studies and case-control studies [21]. and assess the methodological quality using the checklist recommended by Agency for Healthcare Research and Quality (AHRQ) [22]. Cohort studies and case-control studies were classified as having low ( $\geq 7$ stars), moderate (5-6 stars), and high risk of bias ( $\leq 4$ stars) with an overall quality score of 9 stars. For cross-sectional studies, we assigned each item of the AHRQ checklist a score of 1 (answered "yes") or 0 (answered "no" or "unclear"), and summarized scores across items to generate an overall quality score that ranged from 0 to 11 . Low, moderate, and high risk of bias were identified as having a score of $8-11,4-7$ and $0-3$, respectively.

Two investigators (LQ and QCY) independently assessed study quality, with disagreements resolved by a third investigator (LJ).

\section{Data synthesis and statistical analysis}

We performed a meta-analysis to pool data from included studies and assess the effectiveness and safety of SARS-CoV-2 vaccines by clinical outcomes (rates of the prevention of COVID-19, the prevention of hospitalization, the prevention of admission to the ICU, the prevention of COVID-19-related death, and adverse events after vaccination). Random-effects or fixedeffects models were used to pool the rates and adjusted estimates across studies separately, based on the heterogeneity between estimates $\left(I^{2}\right)$. Fixed-effects models were used if $I^{2} \leq 50 \%$, which represented low to moderate heterogeneity and random-effects models were used if $I^{2}>50 \%$, representing substantial heterogeneity.

We conducted subgroup analyses to investigate the possible sources of heterogeneity by using vaccine kinds, vaccination status, sample size, and study population as grouping variables. We used the $Q$ test to conduct subgroup comparisons and variables were considered significant between subgroups if the subgroup difference $P$ value was less than 0.05 . Publication bias was assessed by funnel plot and Egger's regression test. We analyzed data using Stata version 16.0 (StataCorp, Texas, USA). 


\section{Results}

A total of 4844 records were searched from the three databases. 2484 duplicates were excluded. After reading titles and abstracts, we excluded 2264 reviews, RCT studies, duplicates and other studies meeting our exclude criteria. Among the 96 studies under full-text review, 41 studies were excluded (Fig. 1). Ultimately, with three grey literatures included, this final meta-analysis comprised 58 eligible studies, including 32 studies $[14,15,17-20$, 23-48] for vaccine effectiveness and 26 studies [49-74] for vaccine safety. Characteristics of included studies are showed in Additional file 1: Table S1, Additional file 2: Table S2. The risk of bias of all studies we included was moderate or low.

\section{Vaccine effectiveness for different clinical outcomes of COVID-19}

We separately reported the vaccine effectiveness (VE) by the first and second dose of vaccines, and conducted subgroup analysis by the days after the first or second dose ( $<7$ days, $\geq 7$ days, $\geq 14$ days, and $\geq 21$ days; studies with no specific days were classified as 1 dose, 2 dose or $\geq 1$ dose).

For the first dose of SARS-CoV-2 vaccines, the pooled VE was $41 \%$ (95\% CI: 28-54\%) for the prevention of SARS-CoV-2 infection, $52 \%$ (95\% CI: $31-73 \%$ ) for the prevention of symptomatic COVID-19, 66\% (95\% CI: 50-81\%) for the prevention of hospital admissions, $45 \%$ (95\% CI: 42-49\%) for the prevention of ICU admissions, and 53\% (95\% CI: 15-91\%) for the prevention of COVID19-related death (Table 1 ). The subgroup, $\geq 21$ days after the first dose, was found to have the highest VE in each clinical outcome of COVID-19, regardless of $\geq 1$ dose group (Table 1).

For the second dose of SARS-CoV-2 vaccines, the pooled VE was $85 \%$ (95\% CI: $81-89 \%$ ) for the prevention of SARS-CoV-2 infection, 97\% (95\% CI: 97-98\%) for the prevention of symptomatic COVID-19, 93\% (95\% CI: 89-96\%) for the prevention of hospital admissions, 96\% (95\% CI: 93-98\%) for the prevention of ICU admissions, and 95\% (95\% CI: 92-98\%) for the prevention of COVID-19-related death (Table 1). VE was 94\%

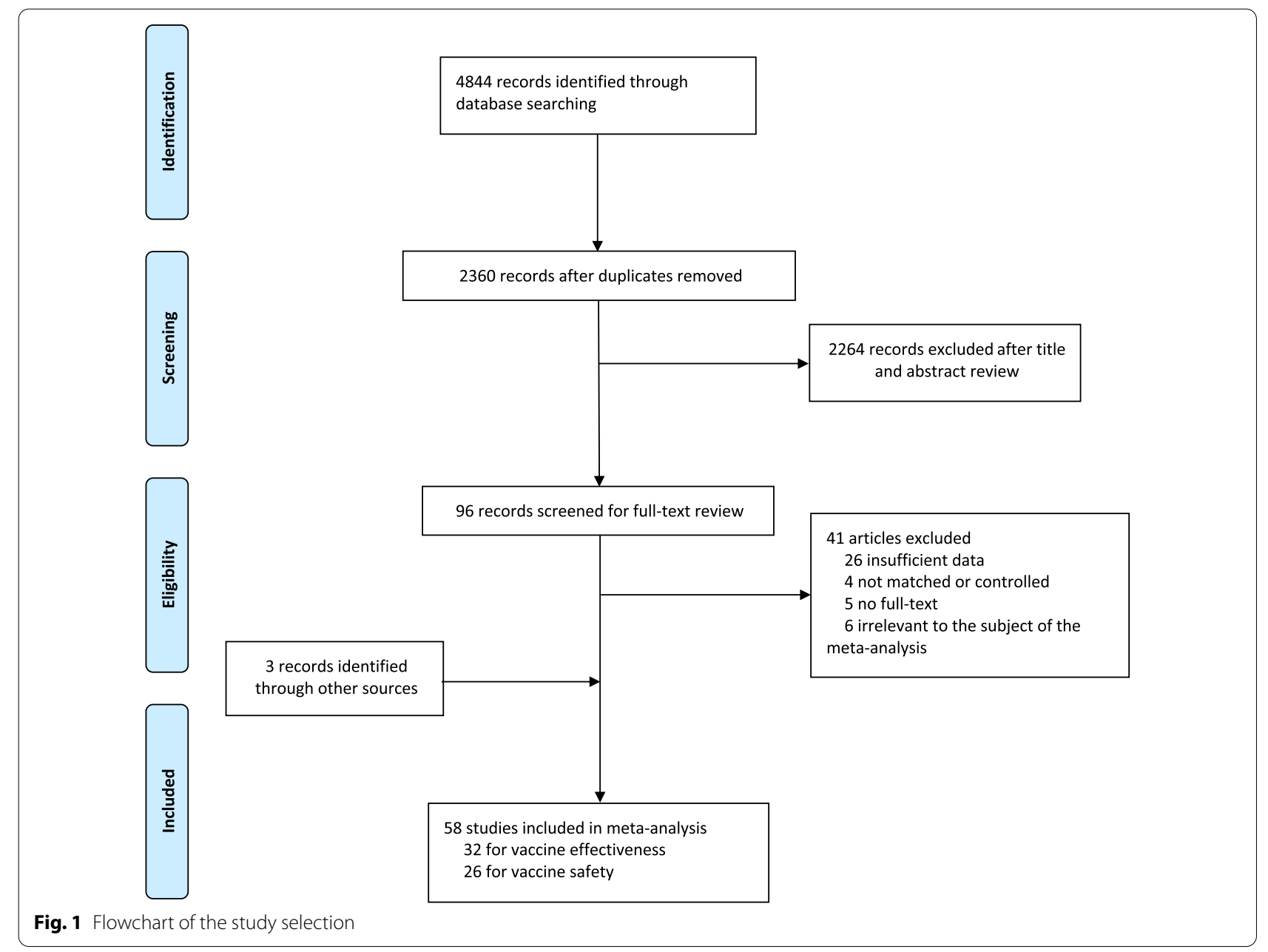


Table 1 Effectiveness of a single dose and two doses of SARS-CoV-2 vaccines

\begin{tabular}{|c|c|c|c|c|c|c|}
\hline & No. cohorts & $\begin{array}{l}\text { Vaccine } \\
\text { effectiveness (\%) } \\
(95 \% \mathrm{Cl})\end{array}$ & $I^{2}(\%)$ & $\begin{array}{l}P \text { value for } \\
\text { heterogeneity }\end{array}$ & $\begin{array}{l}P \text { value for } \\
\text { subgroup } \\
\text { differences }\end{array}$ & Weight (\%) \\
\hline \multicolumn{7}{|l|}{ The first dose } \\
\hline \multicolumn{7}{|l|}{ Prevention of SARS-COV-2 infection } \\
\hline Overall & 44 & $41(28-54)$ & 99.6 & $<0.001$ & $<0.001$ & 100 \\
\hline$<7$ days after the first dose & 3 & $1(-25-27)$ & 84.0 & 0.002 & & 6.92 \\
\hline$<14$ days after the first dose & 4 & $12(0-24)$ & 0.0 & 0.759 & & 6.78 \\
\hline$\geq 7$ days after the first dose & 5 & $17(-20-55)$ & 95.3 & $<0.001$ & & 10.61 \\
\hline$\geq 14$ days after the first dose & 20 & $48(31-66)$ & 99.4 & $<0.001$ & & 46.63 \\
\hline$\geq 21$ days after the first dose & 8 & $56(42-70)$ & 92.6 & $<0.001$ & & 19.45 \\
\hline 1 dose & 3 & $32(9-54)$ & 83.4 & 0.002 & & 7.11 \\
\hline$\geq 1$ dose & 1 & $95(94-96)$ & &. & & 2.50 \\
\hline \multicolumn{7}{|l|}{ Prevention of symptomatic COVID-19 } \\
\hline Overall & 14 & $52(31-73)$ & 99.2 & $<0.001$ & $<0.001$ & 100 \\
\hline$<7$ days after the first dose & 1 & $19(0-45)$ &.. &. & & 6.79 \\
\hline$\geq 7$ days after the first dose & 2 & $45(-43-100)$ & 99.8 & $<0.001$ & & 14.63 \\
\hline$\geq 14$ days after the first dose & 5 & $53(43-62)$ & 64.2 & 0.025 & & 35.24 \\
\hline$\geq 21$ days after the first dose & 2 & $63(7-100)$ & 99.1 & $<0.001$ & & 14.56 \\
\hline 1 dose & 3 & $44(14-74)$ & 94.4 & $<0.001$ & & 21.43 \\
\hline$\geq 1$ dose & 1 & $95(92-97)$ &.. &. & & 7.34 \\
\hline \multicolumn{7}{|c|}{ Prevention of COVID-19 hospital admissions } \\
\hline Overall & 8 & $66(50-81)$ & 98.5 & $<0.001$ & 0.005 & 100 \\
\hline$<7$ days after the first dose & 1 & $74(71-77)$ &. &. & & 13.47 \\
\hline$\geq 7$ days after the first dose & 1 & $61(47-75)$ &.. &.. & & 12.27 \\
\hline$\geq 14$ days after the first dose & 5 & $61(41-81)$ & 97.9 & $<0.001$ & & 60.93 \\
\hline$\geq 21$ days after the first dose & 1 & $82(77-88)$ & &. & & 13.33 \\
\hline \multicolumn{7}{|c|}{ Prevention of COVID-19ICU admissions } \\
\hline Overall & 3 & $45(42-49)$ & 39.5 & 0.192 & .. & 100 \\
\hline$\geq 14$ days after the first dose & 3 & $45(42-49)$ & 39.5 & 0.192 & & 100 \\
\hline \multicolumn{7}{|l|}{ Prevention of COVID-19-related death } \\
\hline Overall & 4 & $53(15-91)$ & 98.9 & $<0.001$ & $<0.001$ & 100 \\
\hline$\geq 14$ days after the first dose & 3 & $44(23-64)$ & 58.1 & 0.092 & & 70.60 \\
\hline$\geq 1$ dose & 1 & $97(91-99)$ & &. & & 29.40 \\
\hline \multicolumn{7}{|l|}{ The second dose } \\
\hline \multicolumn{7}{|l|}{ Prevention of SARS-CoV-2 infection } \\
\hline Overall & 34 & $85(81-89)$ & 99.5 & $<0.001$ & $<0.001$ & 100 \\
\hline$<7$ days after the second dose & 3 & $75(51-99)$ & 95.7 & $<0.001$ & & 8.72 \\
\hline$<14$ days after the second dose & 2 & 70 (49-91) & 70.8 & 0.064 & & 4.77 \\
\hline$\geq 7$ days after the second dose & 14 & $91(88-93)$ & 76.5 & $<0.001$ & & 42.72 \\
\hline$\geq 14$ days after the second dose & 13 & $81(71-92)$ & 99.8 & $<0.001$ & & 37.35 \\
\hline$\geq 21$ days after the second dose & 1 & $94(78-98)$ &. &. & & 2.91 \\
\hline 2 doses & 1 & $98(96-99)$ &. & .. & & 3.52 \\
\hline \multicolumn{7}{|l|}{ Prevention of symptomatic COVID-19 } \\
\hline Overall & 17 & $97(97-98)$ & 83.6 & $<0.001$ & 0.008 & 100 \\
\hline$<7$ days after the second dose & 1 & $100(94-100)$ &. &. & & 5.53 \\
\hline$<14$ days after the second dose & 2 & 75 (59-92) & 46.5 & 0.171 & & 0.47 \\
\hline$\geq 7$ days after the second dose & 5 & $97(96-98)$ & 17.4 & 0.304 & & 32.25 \\
\hline$\geq 14$ days after the second dose & 7 & $96(94-98)$ & 87.9 & $<0.001$ & & 46.53 \\
\hline$\geq 21$ days after the second dose & 1 & $99(94-100)$ &.. &. & & 5.67 \\
\hline 2 doses & 1 & $99(96-100)$ &. & .. & & 9.54 \\
\hline
\end{tabular}


Table 1 (continued)

\begin{tabular}{|c|c|c|c|c|c|c|}
\hline & No. cohorts & $\begin{array}{l}\text { Vaccine } \\
\text { effectiveness (\%) } \\
(95 \% \mathrm{Cl})\end{array}$ & $I^{2}(\%)$ & $\begin{array}{l}P \text { value for } \\
\text { heterogeneity }\end{array}$ & $\begin{array}{l}P \text { value for } \\
\text { subgroup } \\
\text { differences }\end{array}$ & Weight (\%) \\
\hline \multicolumn{7}{|c|}{ Prevention of COVID-19 hospital admissions } \\
\hline Overall & 8 & $93(89-96)$ & 99.0 & $<0.001$ & 0.991 & 100 \\
\hline$\geq 7$ days after the second dose & 3 & $93(84-100)$ & 72.5 & 0.026 & & 35.70 \\
\hline$\geq 14$ days after the second dose & 5 & $93(85-100)$ & 99.4 & $<0.001$ & & 64.3 \\
\hline \multicolumn{7}{|c|}{ Prevention of COVID-19ICU admissions } \\
\hline Overall & 8 & 96 (93-98) & 96.4 & $<0.001$ & 0.414 & 100 \\
\hline$\geq 7$ days after the second dose & 4 & $97(93-100)$ & 18.2 & 0.300 & & 38.11 \\
\hline$\geq 14$ days after the second dose & 4 & $94(87-100)$ & 98.4 & $<0.001$ & & 61.89 \\
\hline \multicolumn{7}{|l|}{ Prevention of COVID-19-related death } \\
\hline Overall & 8 & $95(92-98)$ & 96.3 & $<0.001$ & 0.851 & 100 \\
\hline$<14$ days after the second dose & 1 & $96(83-99)$ &. &. & & 8.68 \\
\hline$\geq 7$ days after the second dose & 3 & $97(95-98)$ & 11.7 & 0.322 & & 37.91 \\
\hline$\geq 14$ days after the second dose & 3 & $93(82-100)$ & 98.9 & $<0.001$ & & 42.36 \\
\hline 2 doses & 1 & $98(87-100)$ & .. & & & 11.06 \\
\hline
\end{tabular}

Cl confidence interval, SARS-CoV-2 severe acute respiratory syndrome coronavirus 2, COVID-19 coronavirus disease 2019

(95\% CI: 78-98\%) in $\geq 21$ days after the second dose for the prevention of SARS-CoV-2 infection, higher than other subgroups, regardless of 2 dose group (Table 1 ). For the prevention of symptomatic COVID-19, VE was also relatively higher in 21 days after the second dose (99\%, 95\% CI: 94-100\%). Subgroups showed no statistically significant differences in the prevention of hospital admissions, ICU admissions and COVID-19-related death (subgroup difference $P$ values were $0.991,0.414$, and 0.851 , respectively).

\section{Vaccine effectiveness for different variants of SARS-CoV-2 in fully vaccinated people}

In the fully vaccinated groups (over 14 days after the second dose), the pooled VE was $85 \%$ (95\% CI: $80-91 \%$ ) for the prevention of Alpha variant of SARS-CoV-2 infection, 54\% (95\% CI: 35-74\%) for the Gamma variant, and 74\% (95\% CI: 62-85\%) for the Delta variant. There was only one study [23] focused on the Beta variant, which showed the VE was 75\% (95\% CI: 71-79\%) for the prevention of the Beta variant of SARS-CoV-2 infection. BNT162b2 vaccine had the highest VE in each variant group; $92 \%$ (95\% CI: 90-94\%) for the Alpha variant, $62 \%$ (95\% CI: 2-88\%) for the Gamma variant, and 84\% (95\% CI: 75-92\%) for the Delta variant (Fig. 2).

For studies which had not mentioned the variant of SARS-CoV-2, the pooled VE was 86\% (95\% CI: 76-97\%) for the prevention of SARS-CoV-2 infection in fully vaccinated people. mRNA-1273 vaccine had the highest pooled VE (97\%, 95\% CI: 93-100\%, Fig. 2).

\section{Safety of SARS-CoV-2 vaccines}

As Table 2 showed, the incidence rate of adverse events varied widely among different studies. We conducted subgroup analysis by study population (general population, patients and healthcare workers), vaccine type (BNT162b2, mRNA-1273, CoronaVac, and et al.), and population size $(<1000,1000-10000,10000-100000$, and $>100000)$. The overall pooled incidence rate was 1.5\% (95\% CI: $1.4-1.6 \%$ ) for adverse events, 0.4 (95\% CI: $0.2-0.5)$ per 10000 for severe adverse events, and 0.1 (95\% CI: 0.1-0.2) per 10000 for death after vaccination. Incidence rate of adverse events was higher in healthcare workers $(53.2 \%, 95 \%$ CI: 28.4-77.9\%), AZD1222 vaccine group (79.6\%, 95\% CI: $60.8-98.3 \%)$, and $<1000$ population size group (57.6\%, 95\% CI: 47.9-67.4\%). Incidence rate of sever adverse events was higher in healthcare workers (127.2, 95\% CI: 62.7-191.8, per 10 000), Gam-COVID-Vac vaccine group $(175.7,95 \%$ CI: $77.2-274.2$, per 10000 ), and $1000-10000$ population size group (336.6, 95\% CI: 41.4-631.8, per 10000 ). Incidence rate of death after vaccination was higher in patients (7.6, 95\% CI: 0.0-32.2, per 10000$)$, BNT162b2 vaccine group $(29.8,95 \% C I: 0.0-71.2$, per 10000$)$, and $<1000$ population size group $(29.8,95 \%$ CI: $0.0-$ 71.2 , per 10000 ). Subgroups of general population, vaccine type not mentioned, and $>100000$ population size had the lowest incidence rate of adverse events, severe adverse events, and death after vaccination. 
A

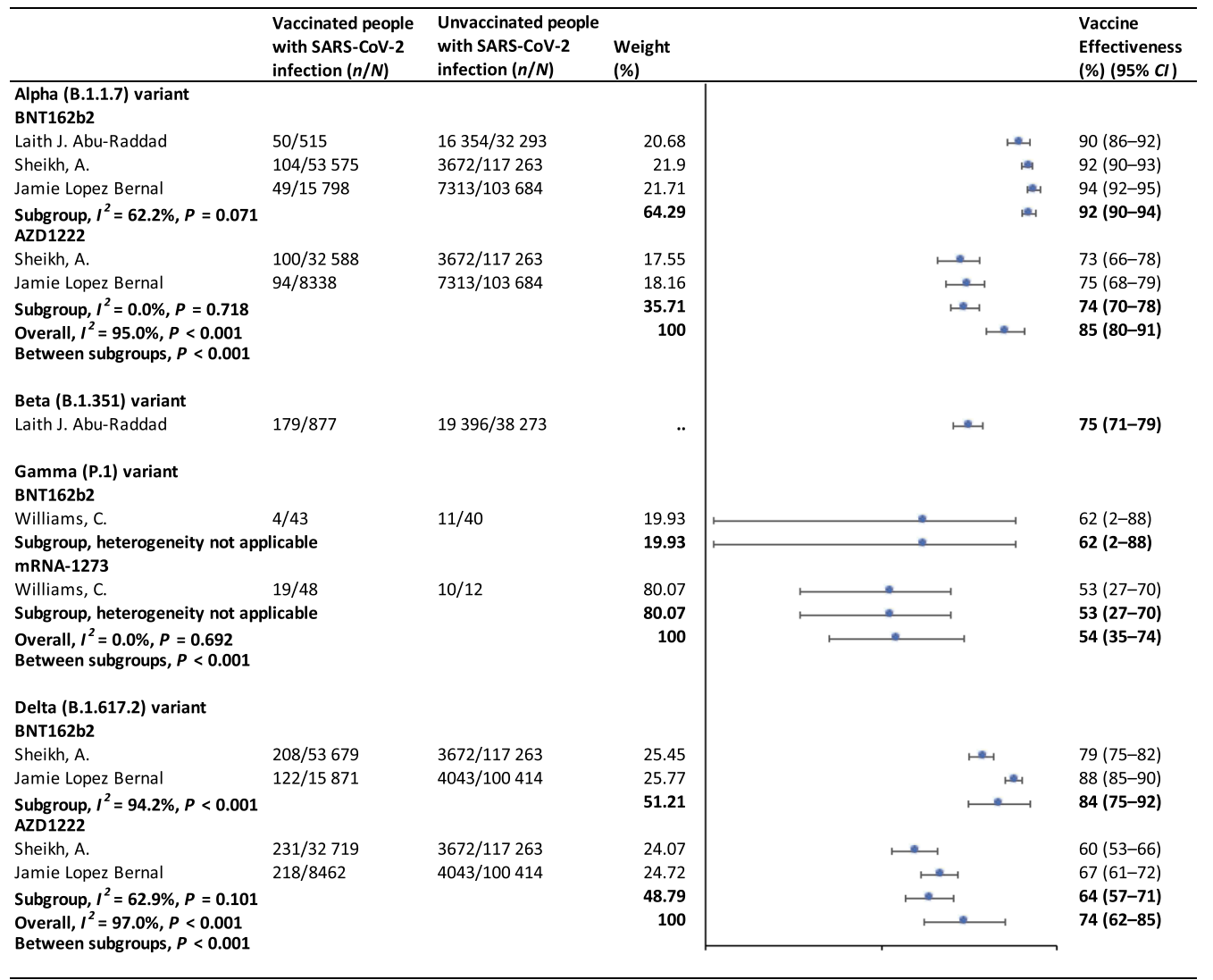

B

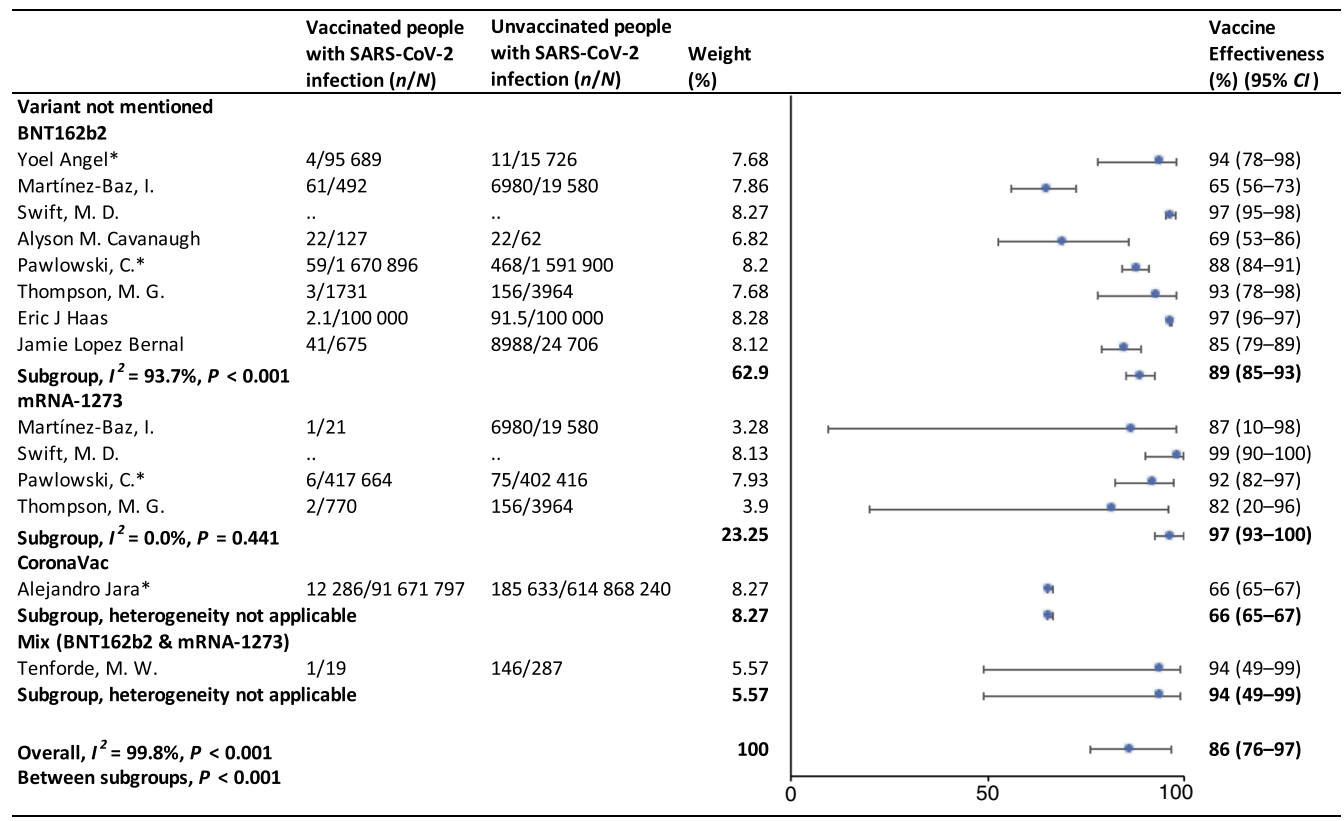

Fig. 2 Forest plots for the vaccine effectiveness of SARS-CoV-2 vaccines in fully vaccinated populations. A Vaccine effectiveness against SARS-CoV-2 variants; B Vaccine effectiveness against SARS-CoV-2 with variants not mentioned. SARS-CoV-2 severe acute respiratory syndrome coronavirus 2 , COVID-19 coronavirus disease 2019, Cl confidence interval 
Table 2 Subgroup analysis of incidence rate of adverse events, sever adverse events and death after SARS-CoV-2 vaccination, by study population, vaccine type, and population size

\begin{tabular}{|c|c|c|c|c|c|c|}
\hline & No. cohorts & $\begin{array}{l}\text { Incidence rate of adverse events } \\
(\%)(95 \% \mathrm{Cl})\end{array}$ & $I^{2}(\%)$ & $\begin{array}{l}P \text { value for } \\
\text { heterogeneity }\end{array}$ & $\begin{array}{l}P \text { value for } \\
\text { subgroup } \\
\text { differences }\end{array}$ & Weight (\%) \\
\hline Overall & 31 & $1.5(1.4-1.6)$ & 100.0 & $<0.001$ & & 100 \\
\hline Study population & & & & & $<0.001$ & \\
\hline General population & 10 & $1.0(0.9-1.0)$ & 100.0 & $<0.001$ & & 98.92 \\
\hline Healthcare workers & 6 & $53.2(28.4-77.9)$ & 99.8 & $<0.001$ & & 0.80 \\
\hline Patients & 15 & $45.7(33.8-57.6)$ & 97.2 & $<0.001$ & & 0.28 \\
\hline Vaccine type & & & & & $<0.001$ & \\
\hline BNT162b2 & 17 & $49.6(21.8-77.4)$ & 99.9 & $<0.001$ & & 23.57 \\
\hline AZD1222 & 4 & $79.6(60.8-98.3)$ & 99.1 & $<0.001$ & & 0.49 \\
\hline mRNA-1273 & 1 & $50.0(34.9-65.1)$ &. &. & & 0.01 \\
\hline CoronaVac & 3 & $30.8(7.8-53.8)$ & 99.7 & $<0.001$ & & 0.63 \\
\hline Ad26.COV2.S & 1 & $0.2(0.2-0.2)$ &. &. & & 25.03 \\
\hline Gam-COVID-Vac & 1 & $71.3(67.9-74.7)$ &.. &. & & 0.08 \\
\hline BBIBP-CorV & 1 & $29.4(24.8-34.0)$ &.. &.. & & 0.04 \\
\hline Any & 3 & $0.0(0.0-0.1)$ & 100.0 & $<0.001$ & & 50.15 \\
\hline Population size & & & & & $<0.001$ & \\
\hline$<1000$ & 24 & $57.6(47.9-67.4)$ & 99.2 & $<0.001$ & & 1.41 \\
\hline 1000-10000 & 3 & $29.1(3.3-54.9)$ & 99.8 & $<0.001$ & & 0.75 \\
\hline $10000-100000$ & 1 & $0.4(0.3-0.4)$ &. &.. & & 22.74 \\
\hline \multirow[t]{2}{*}{$>100000$} & 3 & $0.1(0.0-0.1)$ & 100.0 & $<0.001$ & & 75.11 \\
\hline & No. cohorts & $\begin{array}{l}\text { Incidence rate of severe adverse } \\
\text { events (per } 10000)(95 \% \mathrm{Cl})\end{array}$ & $I^{2}(\%)$ & $\begin{array}{l}P \text { value for } \\
\text { heterogeneity }\end{array}$ & $\begin{array}{l}P \text { value for } \\
\text { subgroup } \\
\text { differences }\end{array}$ & Weight (\%) \\
\hline Overall & 15 & $0.4(0.2-0.5)$ & 98.2 & $<0.001$ & & 100 \\
\hline Study population & & & & & $<0.001$ & \\
\hline General population & 9 & $0.4(0.2-0.5)$ & 98.9 & $<0.001$ & & 84.53 \\
\hline Healthcare workers & 2 & $127.2(62.7-191.8)$ & 36.1 & 0.211 & & 0.01 \\
\hline Patients & 4 & $22.5(0.0-72.6)$ & 77.7 & 0.004 & & 15.46 \\
\hline Vaccine type & & & & & $<0.001$ & \\
\hline BNT162b2 & 5 & $8.1(0.0-17.8)$ & 98.2 & $<0.001$ & & 7.71 \\
\hline mRNA-1273 & 2 & $4.2(0.0-16.3)$ & 43.9 & 0.182 & & 0.83 \\
\hline CoronaVac & 1 & 104.8 (53.7-156.0) &. &.. & & 0.01 \\
\hline Ad26.COV2.S & 1 & $0.4(0.4-0.5)$ &.. &.. & & 18.84 \\
\hline Gam-COVID-Vac & 1 & 175.7 (77.2-274.2) &.. &.. & & 0.01 \\
\hline Any & 5 & $0.3(0.2-0.5)$ & 99.1 & $<0.001$ & & 72.60 \\
\hline Population size & & & & & 0.030 & \\
\hline$<1000$ & 4 & $90.4(0.0-193.5)$ & 82.7 & 0.001 & & 0.01 \\
\hline 1000-10000 & 3 & 336.6 (41.4-631.8) & 99.0 & $<0.001$ & & 0.01 \\
\hline $10000-100000$ & 3 & $1.0(0.0-2.2)$ & 73.3 & 0.024 & & 8.54 \\
\hline \multirow[t]{2}{*}{$>100000$} & 5 & $0.4(0.2-0.5)$ & 99.2 & $<0.001$ & & 91.45 \\
\hline & No. cohorts & $\begin{array}{l}\text { Incidence rate of death after } \\
\text { vaccination (per } 10000)(95 \% \mathrm{Cl})\end{array}$ & $I^{2}(\%)$ & $\begin{array}{l}P \text { value for } \\
\text { heterogeneity }\end{array}$ & $\begin{array}{l}P \text { value for } \\
\text { subgroup } \\
\text { differences }\end{array}$ & Weight (\%) \\
\hline Overall & 5 & $0.1(0.1-0.2)$ & 87.6 & $<0.001$ & & 100 \\
\hline Study population & & & & & 0.549 & \\
\hline General population & 3 & $0.1(0.1-0.1)$ & 55.4 & 0.106 & & 94.73 \\
\hline Patients & 2 & $7.6(0.0-32.2)$ & 48.3 & 0.164 & & 5.27 \\
\hline Vaccine type & & & & & 0.319 & \\
\hline
\end{tabular}


Table 2 (continued)

\begin{tabular}{|c|c|c|c|c|c|c|}
\hline & No. cohorts & $\begin{array}{l}\text { Incidence rate of death after } \\
\text { vaccination (per } 10000)(95 \% \mathrm{Cl})\end{array}$ & $I^{2}(\%)$ & $\begin{array}{l}P \text { value for } \\
\text { heterogeneity }\end{array}$ & $\begin{array}{l}P \text { value for } \\
\text { subgroup } \\
\text { differences }\end{array}$ & Weight (\%) \\
\hline BNT162b2 & 1 & $29.8(0.0-71.2)$ &.. &.. & & 0.01 \\
\hline Ad26.COV2.S & 1 & $0.1(0.1-0.1)$ & .. &.. & & 30.92 \\
\hline Any & 3 & $0.1(0.1-0.2)$ & 92.4 & $<0.001$ & & 69.07 \\
\hline Population size & & & & & 0.158 & \\
\hline$<1000$ & 1 & $29.8(0.0-71.2)$ &.. &. & & 0.01 \\
\hline$>100000$ & 4 & $0.1(0.1-0.2)$ & 90.0 & $<0.001$ & & 99.9 \\
\hline
\end{tabular}

$\mathrm{Cl}$ confidence interval

\section{Sensitivity analysis and publication bias}

In the sensitivity analyses, VE for SARS-CoV-2 infections, symptomatic COVID-19 and COVID-19-related death got relatively lower when omitting over a single dose group of Maria et al's work [33]; when omitting $\geq 14$ days after the first dose group and $\geq 14$ days after the second dose group of Alejandro et al's work [14], VE for SARS$\mathrm{CoV}-2$ infections, hospitalization, ICU admission and COVID-19-related death got relatively higher; and VE for all clinical status of COVID-19 became lower when omitting $\geq 14$ days after the second dose group of Eric et al's work [34]. Incidence rate of adverse events and severe adverse events got relatively higher when omitting China CDC's data [74]. $P$ values of Egger's regression test for all the meta-analysis were more than 0.05 , indicating that there might not be publication bias.

\section{Discussion}

To our knowledge, this is a comprehensive systematic review and meta-analysis assessing the effectiveness and safety of SARS-CoV-2 vaccines based on real-world studies, reporting pooled VE for different variants of SARS-CoV-2 and incidence rate of adverse events. This meta-analysis comprised a total of 58 studies, including 32 studies for vaccine effectiveness and 26 studies for vaccine safety. We found that a single dose of SARSCoV-2 vaccines was about $40-60 \%$ effective at preventing any clinical status of COVID-19 and that two doses were $85 \%$ or more effective. Although vaccines were not as effective against variants of SARS-CoV-2 as original virus, the vaccine effectiveness was still over $50 \%$ for fully vaccinated people. Normal adverse events were common, while the incidence of severe adverse events or even death was very low, providing reassurance to health care providers and to vaccine recipients and promote confidence in the safety of COVID-19 vaccines. Our findings strengthen and augment evidence from previous review [75], which confirmed the effectiveness of the BNT162b2 mRNA vaccine, and additionally reported the safety of
SARS-CoV-2 vaccines, giving insight on the future of SARS-CoV-2 vaccine schedules.

Although most vaccines for the prevention of COVID19 are two-dose vaccines, we found that the pooled VE of a single dose of SARS-CoV-2 vaccines was about $50 \%$. Recent study showed that the $\mathrm{T}$ cell and antibody responses induced by a single dose of the BNT162b2 vaccine were comparable to those naturally infected with SARE-CoV-2 within weeks or months after infection [76]. Our findings could help to develop vaccination strategies under certain circumstances such as countries having a shortage of vaccines. In some countries, in order to administer the first dose to a larger population, the second dose was delayed for up to 12 weeks [77]. Some countries such as Canada had even decided to delay the second dose for 16 weeks [78]. However, due to a suboptimum immune response in those receiving only a single dose of a vaccine, such an approach had a chance to give rise to the emergence of variants of SARS-CoV-2 [79]. There remains a need for large clinical trials to assess the efficacy of a single-dose administration of two-dose vaccines and the risk of increasing the emergence of variants.

Two doses of SARS-CoV-2 vaccines were highly effective at preventing hospitalization, severe cases and deaths resulting from COVID-19, while the VE of different groups of days from the second vaccine dose showed no statistically significant differences. Our findings emphasized the importance of getting fully vaccinated, for the fact that most breakthrough infections were mild or asymptomatic. A recent study showed that the occurrence of breakthrough infections with SARS-CoV-2 in fully vaccinated populations was predictable with neutralizing antibody titers during the peri-infection period [80]. We also found getting fully vaccinated was at least $50 \%$ effective at preventing SARS-CoV-2 variants infections, despite reduced effectiveness compared with original virus; and BNT162b2 vaccine was found to have the highest VE in each variant group. Studies showed that the highly mutated variants were indicative of a form of 
rapid, multistage evolutionary jumps, which could preferentially occur in the milieu of partial immune control [81, 82]. Therefore, immunocompromised patients should be prioritized for anti-COVID-19 immunization to mitigate persistent SARS-CoV-2 infections, during which multimutational SARS-CoV-2 variants could arise [83].

Recently, many countries, including Israel, the United States, China and the United Kingdom, have introduced a booster of COVID-19 vaccine, namely the third dose [84-87]. A study of Israel showed that among people vaccinated with BNT162b2 vaccine over 60 years, the risk of COVID-19 infection and severe illness in the nonbooster group was 11.3 times (95\% CI: 10.4-12.3) and 19.5 times (95\% CI: 12.9-29.5) than the booster group, respectively [84]. Some studies have found that the third dose of Moderna, Pfizer-BioNTech, Oxford-AstraZeneca and Sinovac produced a spike in infection-blocking neutralizing antibodies when given a few months after the second dose $[85,87,88]$. In addition, the common adverse events associated with the third dose did not differ significantly from the symptoms of the first two doses, ranging from mild to moderate [85]. The overall incidence rate of local and systemic adverse events was $69 \%$ (57/97) and 20\% (19/97) after receiving the third dose of BNT162b2 vaccine, respectively [88]. Results of a phase 3 clinical trial involving 306 people aged $18-55$ years showed that adverse events after receiving a third dose of BNT162b2 vaccine (5-8 months after completion of two doses) were similar to those reported after receiving a second dose [85]. Based on V-safe, local reactions were more frequently after dose $3(5323 / 6283 ; 84.7 \%)$ than dose 2 (5249/6283; 83.5\%) among people who received 3 doses of Moderna. Systemic reactions were reported less frequently after dose $3(4963 / 6283 ; 79.0 \%)$ than dose 2 (5105/6283; 81.3\%) [86]. On August 4, WHO called for a halt to booster shots until at least the end of September to achieve an even distribution of the vaccine [89]. At this stage, the most important thing we should be thinking about is how to reach a global cover of people at risk with the first or second dose, rather than focusing on the third dose.

Based on real world studies, our results preliminarily showed that complete inoculation of COVID-19 vaccines was still effective against infection of variants, although the VE was generally diminished compared with the original virus. Particularly, the pooled VE was $54 \%$ (95\% CI: $35-74 \%$ ) for the Gamma variant, and 74\% (95\% CI: $62-85 \%)$ for the Delta variant. Since the wide spread of COVID-19, a number of variants have drawn extensive attention of international community, including Alpha variant (B.1.1.7), first identified in the United Kingdom; Beta variant (B.1.351) in South Africa; Gamma variant (P.1), initially appeared in Brazil; and the most infectious one to date, Delta variant (B.1.617.2) [90]. Israel recently reported a breakthrough infection of SARS-CoV-2, dominated by variant B.1.1.7 in a small number of fully vaccinated health care workers, raising concerns about the effectiveness of the original vaccine against those variants [80]. According to an observational cohort study in Qatar, VE of the BNT162b2 vaccine against the Alpha (B.1.1.7) and Beta (B.1.351) variants was $87 \%$ (95\% CI: 81.8-90.7\%) and 75.0\% (95\% CI: 70.5-7.9\%), respectively [23]. Based on the National Immunization Management System of England, results from a recent real-world study of all the general population showed that the AZD1222 and BNT162b2 vaccines protected against symptomatic SARS-CoV-2 infection of Alpha variant with 74.5\% (95\% CI: 68.4-79.4\%) and 93.7\% (95\% CI: 91.6-95.3\%) [15]. In contrast, the VE against the Delta variant was 67.0\% (95\% CI: 61.3-71.8\%) for two doses of AZD1222 vaccine and 88\% (95\% CI: 85.3-90.1\%) for BNT162b2 vaccine [15].

In terms of adverse events after vaccination, the pooled incidence rate was very low, only 1.5\% (95\% CI: 1.4-1.6\%). However, the prevalence of adverse events reported in large population (population size $>100$ 000) was much lower than that in small to medium population size. On the one hand, the vaccination population in the small to medium scale studies we included were mostly composed by health care workers, patients with specific diseases or the elderly. And these people are more concerned about their health and more sensitive to changes of themselves. But it remains to be proved whether patients or the elderly are more likely to have adverse events than the general. Mainstream vaccines currently on the market have maintained robust safety in specific populations such as cancer patients, organ transplant recipients, patients with rheumatic and musculoskeletal diseases, pregnant women and the elderly [54, 91-94]. A prospective study by Tal Goshen-lag suggests that the safety of BNT162b2 vaccine in cancer patients is consistent with those previous reports [91]. In addition, the incidence rate of adverse events reported in the heart-lung transplant population is even lower than that in general population [95]. On the other hand, large scale studies at the national level are mostly based on national electronic health records or adverse event reporting systems, and it is likely that most mild or moderate symptoms are actually not reported.

Compared with the usual local adverse events (such as pain at the injection site, redness at the injection site, etc.) and normal systemic reactions (such as fatigue, myalgia, etc.), serious and life-threatening adverse events were rare due to our results. A meta-analysis based on RCTs only showed three cases of anaphylactic shock among 58 889 COVID-19 vaccine recipients and one in the placebo group [11]. The exact mechanisms underlying most of the 
adverse events are still unclear, accordingly we cannot establish a causal relation between severe adverse events and vaccination directly based on observational studies. In general, varying degrees of adverse events occur after different types of COVID-19 vaccination. Nevertheless, the benefits far outweigh the risks.

Our results showed the effectiveness and safety of different types of vaccines varied greatly. Regardless of SARS-CoV-2 variants, vaccine effectiveness varied from 66\% (CoronaVac [14]) to 97\% (mRNA-1273 [18, 20, 45, 46]). The incidence rate of adverse events varied widely among different types of vaccines, which, however, could be explained by the sample size and population group of participants. BNT162b2, AZD1222, mRNA-1273 and CoronaVac were all found to have high vaccine efficacy and acceptable adverse-event profile in recent published studies [96-99]. A meta-analysis, focusing on the potential vaccine candidate which have reached to the phase 3 of clinical development, also found that although many of the vaccines caused more adverse events than the controls, most were mild, transient and manageable [100]. However, severe adverse events did occur, and there remains the need to implement a unified global surveillance system to monitor the adverse events of COVID19 vaccines around the world [101]. A recent study employed a knowledge-based or rational strategy to perform a prioritization matrix of approved COVID-19 vaccines, and led to a scale with JANSSEN (Ad26.COV2.S) in the first place, and AZD1222, BNT162b2, and Sputnik $\mathrm{V}$ in second place, followed by BBIBP-CorV, CoronaVac and mRNA-1273 in third place [101]. Moreover, when deciding the priority of vaccines, the socioeconomic characteristics of each country should also be considered.

Our meta-analysis still has several limitations. First, we may include limited basic data on specific populations, as vaccination is slowly being promoted in populations under the age of 18 or over 60 . Second, due to the limitation of the original real-world study, we did not conduct subgroup analysis based on more population characteristics, such as age. When analyzing the efficacy and safety of COVID-19 vaccine, we may have neglected the discussion on the heterogeneity from these sources. Third, most of the original studies only collected adverse events within 7 days after vaccination, which may limit the duration of follow-up for safety analysis.

\section{Conclusions}

Based on the real-world studies, SARS-CoV-2 vaccines have reassuring safety and could effectively reduce the death, severe cases, symptomatic cases, and infections resulting from SARS-CoV-2 across the world. In the context of global pandemic and the continuous emergence of SARS-CoV-2 variants, accelerating vaccination and improving vaccination coverage is still the most important and urgent matter, and it is also the final means to end the pandemic.

\section{Abbreviations}

COVID-19: Coronavirus disease 2019; SARS-CoV-2: Severe Acute Respiratory Syndrome Coronavirus 2; VE: Vaccine effectiveness; Cl: Confidence intervals; ICU: Intensive care unit; RCT: Random clinical trials; PRISMA: Preferred reporting items for systematic reviews and meta-analyses.

\section{Supplementary Information}

The online version contains supplementary material available at https://doi. org/10.1186/s40249-021-00915-3.

Additional file 1: Table S1. Characteristic of studies included for vaccine effectiveness.

Additional file 2: Table S2. Characteristic of studies included for vaccine safety.

\section{Acknowledgements}

None.

\section{Authors' contributions}

LQ and QCY contributed equally as first authors. LJ and LM contributed equally as correspondence authors. $L J$ and LM conceived and designed the study; LQ, QCY and LJ carried out the literature searches, extracted the data, and assessed the study quality; LQ and QCY performed the statistical analysis and wrote the manuscript; L, LM, LQ and QCY revised the manuscript. All authors read and approved the final manuscript.

\section{Funding}

This study was funded by the National Natural Science Foundation of China $(72122001 ; 71934002)$ and the National Science and Technology Key Projects on Prevention and Treatment of Major infectious disease of China (2020ZX10001002). The funders had no role in study design, data collection and analysis, decision to publish, or preparation of the paper. No payment was received by any of the co-authors for the preparation of this article.

\section{Availability of data and materials}

All data generated or analyzed during this study are included in this published article and its additional information files.

\section{Declarations}

Ethics approval and consent to participate

Not applicable.

\section{Consent for publication}

Not applicable.

\section{Competing interests}

The authors have no conflicts of interest to declare that are relevant to the content of this article.

\section{Author details}

'Department of Epidemiology and Biostatistics, School of Public Health, Peking University, Beijing 100191, China. ${ }^{2}$ Institute for Global Health and Development, Peking University, Beijing 100871, China.

Received: 7 September 2021 Accepted: 1 November 2021

Published online: 14 November 2021 


\section{References}

1. COVID-19 Dashboard by the Center for Systems Science and Engineering (CSSE) at Johns Hopkins University (JHU). 2021. https://coronavirus. jhu.edu/map.html. Accessed 20 Aug 2021.

2. Barranco R, Rocca G, Molinelli A, Ventura F. Controversies and challenges of mass vaccination against SARS-CoV-2 in Italy: medico-legal perspectives and considerations. Healthcare (Basel). 2021. https://doi. org/10.3390/healthcare9091163.

3. COVID-19 vaccine tracker. 2021. https://vac-Ishtm.shinyapps.io/ncov_ vaccine_landscape/. Accessed 20 Aug 2021.

4. Coronavirus (COVID-19) Vaccinations. 2021. https://ourworldindata.org/ covid-vaccinations. Accessed 20 Aug 2021

5. Kirby T. New variant of SARS-CoV-2 in UK causes surge of COVID-19. Lancet Respir Med. 2021;9(2):e20-1. https://doi.org/10.1016/s22132600(21)00005-9.

6. Callaway E. Fast-spreading COVID variant can elude immune responses. Nature. 2021;589(7843):500-1. https://doi.org/10.1038/ d41586-021-00121-z.

7. Reardon S. How the Delta variant achieves its ultrafast spread. Nature. 2021. https://doi.org/10.1038/d41586-021-01986-w.

8. Li R, Liu J, Zhang H. The challenge of emerging SARS-CoV-2 mutants to vaccine development. J Genet Genomics. 2021;48(2):102-6. https://doi. org/10.1016/j.jgg.2021.03.001.

9. Chen M, Yuan Y, Zhou Y, Deng Z, Zhao J, Feng F, Zou H, Sun C. Safety of SARS-CoV-2 vaccines: a systematic review and meta-analysis of randomized controlled trials. Infect Dis Poverty. 2021;10(1):94. https:// doi.org/10.1186/s40249-021-00878-5.

10. Ling Y, Zhong J, Luo J. Safety and effectiveness of SARS-CoV-2 vaccines: a systematic review and meta-analysis. J Med Virol. 2021. https://doi. org/10.1002/jmv.27203.

11. Pormohammad A, Zarei M, Ghorbani S, Mohammadi M, Razizadeh MH, Turner DL, Turner RJ. Efficacy and safety of COVID-19 vaccines: a systematic review and meta-analysis of randomized clinical trials. Vaccines (Basel). 2021. https://doi.org/10.3390/vaccines9050467.

12. Sathian B, Asim M, Banerjee I, Roy B, Pizarro AB, Mancha MA, van Teijlingen ER, Kord-Varkaneh H, Mekkodathil AA, Subramanya SH, et al. Development and implementation of a potential coronavirus disease 2019 (COVID-19) vaccine: a systematic review and meta-analysis of vaccine clinical trials. Nepal J Epidemiol. 2021;11(1):959-82. https://doi.org/ 10.3126/nje.v11i1.36163

13. Yuan P, Ai P, Liu Y, Ai Z, Wang Y, Cao W, Xia X, Zheng JC. Safety, tolerability, and immunogenicity of COVID-19 vaccines: a systematic review and meta-analysis. medRxiv. 2020. https://doi.org/10.1101/2020.11.03.20224 998.

14. Jara A, Undurraga EA, González C, Paredes F, Fontecilla T, Jara G, Pizarro A, Acevedo J, Leo K, Leon F, et al. Effectiveness of an inactivated SARSCoV-2 vaccine in Chile. N Engl J Med. 2021. https://doi.org/10.1056/ NEJMoa2107715.

15. Lopez Bernal J, Andrews N, Gower C, Gallagher E, Simmons R, Thelwall S, Stowe J, Tessier E, Groves N, Dabrera G, et al. Effectiveness of COVID19 vaccines against the B.1.617.2 (Delta) variant. N Engl J Med. 2021. https://doi.org/10.1056/NEJMoa2108891.

16. Israel says Pfizer Covid vaccine is just $39 \%$ effective as delta spreads, but still prevents severe illness. 2021. https://www.cnbc.com/2021/07/23/ delta-variant-pfizer-covid-vaccine-39percent-effective-in-israel-preve nts-severe-illness.html. Accessed 20 Aug 2021.

17. Zacay G, Shasha D, Bareket R, Kadim I, Hershkowitz Sikron F, Tsamir J Mossinson D, Heymann AD. BNT162b2 vaccine effectiveness in preventing asymptomatic infection with SARS-CoV-2 virus: a nationwide historical cohort study. Open Forum Infect Dis. 2021;8(6): ofab262. https://doi.org/10.1093/ofid/ofab262.

18. Martínez-Baz I, Miqueleiz A, Casado I, Navascués A, Trobajo-Sanmartín C, Burgui C, Guevara M, Ezpeleta C, Castilla J. Effectiveness of COVID-19 vaccines in preventing SARS-CoV-2 infection and hospitalisation, Navarre, Spain, January to April 2021. Eurosurveillance. 2021. https://doi. org/10.2807/1560-7917.Es.2021.26.21.2100438.

19. Tenforde MW, Olson SM, Self WH, Talbot HK, Lindsell CJ, Steingrub JS, Shapiro NI, Ginde AA, Douin DJ, Prekker ME, et al. Effectiveness of PfizerBioNTech and moderna vaccines against COVID-19 among hospitalized adults aged $\geq 65$ years-United States, January-March 2021. MMWR
Morb Mortal Wkly Rep. 2021;70(18):674-9. https://doi.org/10.15585/ mmwr.mm7018e1.

20. Pawlowski C, Lenehan P, Puranik A, Agarwal V, Venkatakrishnan AJ, Niesen MJM, O'Horo JC, Virk A, Swift MD, Badley AD, et al. FDA-authorized mRNA COVID-19 vaccines are effective per real-world evidence synthesized across a multi-state health system. Med (N Y). 2021. https:// doi.org/10.1016/j.medj.2021.06.007.

21. Wells G, Shea B, O'Connell D, Peterson J, Welch V, Losos M, Tugwell P. The Newcastle-Ottawa Scale (NOS) for assessing the quality of nonrandomised studies in meta-analyses. http://www.ohri.ca/programs/clini cal_epidemiology/oxford.asp. Accessed 20 Aug 2021.

22. Rostom A, Dubé C, Cranney A, et al. Celiac Disease. Rockville (MD): Agency for Healthcare Research and Quality (US); 2004 Sep. (Evidence Reports/Technology Assessments, No. 104.) Appendix D. Quality Assess ment Forms. Available from: https://www.ncbi.nlm.nih.gov/books/ NBK35156/. Accessed 20 Aug 2021

23. Abu-Raddad LJ, Chemaitelly H, Butt AA. Effectiveness of the BNT162b2 COVID-19 vaccine against the B.1.1.7 and B.1.351 Variants. N Engl J Med. 2021;385(2):187-9. https://doi.org/10.1056/NEJMc2104974.

24. Angel Y, Spitzer A, Henig O, Saiag E, Sprecher E, Padova H, Ben-Ami R. Association between vaccination with BNT162b2 and incidence of symptomatic and asymptomatic SARS-CoV-2 infections among health care workers. JAMA. 2021;325(24):2457-65. https://doi.org/10.1001/ jama.2021.7152.

25. Azamgarhi T, Hodgkinson M, Shah A, Skinner JA, Hauptmannova I, Briggs TWR, Warren S. BNT162b2 vaccine uptake and effectiveness in UK healthcare workers - a single centre cohort study. Nat Commun. 2021;12(1):3698. https://doi.org/10.1038/s41467-021-23927-x.

26. Bianchi FP, Germinario CA, Migliore G, Vimercati L, Martinelli A, Lobifaro A, Tafuri S, Stefanizzi P. BNT162b2 mRNA COVID-19 vaccine effectiveness in the prevention of SARS-CoV-2 infection: a preliminary report. J Infect Dis. 2021. https://doi.org/10.1093/infdis/jiab262.

27. Britton A, Jacobs Slifka KM, Edens C, Nanduri SA, Bart SM, Shang N, Harizaj A, Armstrong J, Xu K, Ehrlich HY, et al. Effectiveness of the PfizerBioNTech COVID-19 vaccine among residents of two skilled nursing facilities experiencing COVID-19 outbreaks-Connecticut, December 2020-February 2021. MMWR Morb Mortal Wkly Rep. 2021;70(11):396401. https://doi.org/10.15585/mmwr.mm7011e3.

28. Cavanaugh AM, Fortier S, Lewis P, Arora V, Johnson M, George K, Tobias J, Lunn S, Miller T, Thoroughman D, et al. COVID-19 outbreak associated with a SARS-CoV-2 R1 lineage variant in a skilled nursing facility after vaccination program-Kentucky, March 2021. MMWR Morb Mortal Wkly Rep. 2021;70(17):639-43. https://doi.org/10.15585/mmwr.mm701 7 e2.

29. Chemaitelly H, Yassine HM, Benslimane FM, Al Khatib HA, Tang P, Hasan MR, Malek JA, Coyle P, Ayoub HH, Al Kanaani Z, et al. mRNA-1273 COVID-19 vaccine effectiveness against the B.1.1.7 and B.1.351 variants and severe COVID-19 disease in Qatar. Nat Med. 2021. https://doi.org/ 10.1038/s41591-021-01446-y.

30. Chodick G, Tene L, Patalon T, Gazit S, Ben Tov A, Cohen D, Muhsen K. Assessment of effectiveness of 1 dose of BNT162b2 vaccine for SARSCoV-2 infection 13 to 24 days after immunization. JAMA Netw Open. 2021;4(6): e2115985. https://doi.org/10.1001/jamanetworkopen.2021. 15985.

31. Chodick G, Tene L, Rotem RS, Patalon T, Gazit S, Ben-Tov A, Weil C, Goldshtein I, Twig G, Cohen D, et al. The effectiveness of the TWO-DOSE BNT162b2 vaccine: analysis of real-world data. Clin Infect Dis. 2021. https://doi.org/10.1093/cid/ciab438.

32. Dagan N, Barda N, Kepten E, Miron O, Perchik S, Katz MA, Hernán MA, Lipsitch M, Reis B, Balicer RD. BNT162b2 mRNA COVID-19 vaccine in a nationwide mass vaccination setting. N Engl J Med. 2021;384(15):141223. https://doi.org/10.1056/NEJMoa2101765.

33. Flacco ME, Soldato G, Acuti Martellucci C, Carota R, Di Luzio R, Caponetti A, Manzoli L. Interim estimates of COVID-19 vaccine effectiveness in a mass vaccination setting: data from an Italian Province. VacCInes (Basel). 2021. https://doi.org/10.3390/vaccines9060628.

34. Haas EJ, Angulo FJ, McLaughlin JM, Anis E, Singer SR, Khan F, Brooks N, Smaja M, Mircus G, Pan K, et al. Impact and effectiveness of mRNA BNT162b2 vaccine against SARS-CoV-2 infections and COVID-19 cases, hospitalisations, and deaths following a nationwide vaccination campaign in Israel: an observational study using national surveillance 
data. Lancet. 2021;397(10287):1819-29. https://doi.org/10.1016/s01406736(21)00947-8

35. Hall VJ, Foulkes S, Saei A, Andrews N, Oguti B, Charlett A, Wellington E, Stowe J, Gillson N, Atti A, et al. COVID-19 vaccine coverage in healthcare workers in England and effectiveness of BNT162b2 mRNA vaccine against infection (SIREN): a prospective, multicentre, cohort study. Lancet. 2021;397(10286):1725-35. https://doi.org/10.1016/s0140-6736(21) 00790-x.

36. Hyams C, Marlow R, Maseko Z, King J, Ward L, Fox K, Heath R, Tuner A, Friedrich Z, Morrison L, et al. Effectiveness of BNT162b2 and ChAdOx1 $n C o V-19$ COVID-19 vaccination at preventing hospitalisations in people aged at least 80 years: a test-negative, case-control study. Lancet Infect Dis. 2021. https://doi.org/10.1016/s1473-3099(21)00330-3.

37. Khan N, Mahmud N. Effectiveness of SARS-CoV-2 vaccination in a veterans affairs cohort of patients with inflammatory bowel disease with diverse exposure to immunosuppressive medications. Gastroenterology. 2021. https://doi.org/10.1053/j.gastro.2021.05.044.

38. Knobel P, Serra C, Grau S, Ibañez R, Diaz P, Ferrández O, Villar R, Lopez AF, Pujolar N, Horcajada JP, et al. COVID-19 mRNA vaccine effectiveness in asymptomatic healthcare workers. Infect Control Hosp Epidemiol. 2021. https://doi.org/10.1017/ice.2021.287.

39. Lopez Bernal J, Andrews N, Gower C, Robertson C, Stowe J, Tessier E, Simmons R, Cottrell S, Roberts R, O'Doherty M, et al. Effectiveness of the Pfizer-BioNTech and Oxford-AstraZeneca vaccines on covid-19 related symptoms, hospital admissions, and mortality in older adults in England: test negative case-control study. BMJ. 2021;373: n1088. https:// doi.org/10.1136/bmj.n1088.

40. Mazagatos $C$, Monge S, Olmedo C, Vega L, Gallego P, Martín-Merino E, Sierra MJ, Limia A, Larrauri A. Effectiveness of mRNA COVID-19 vaccines in preventing SARS-CoV-2 infections and COVID-19 hospitalisations and deaths in elderly long-term care facility residents, Spain, weeks 53, 2020 to 13 2021. Eurosurveillance. 2021. https://doi.org/10.2807/1560-7917. Es.2021.26.24.2100452.

41. Pilishvili T, Fleming-Dutra KE, Farrar JL, Gierke R, Mohr NM, Talan DA, Krishnadasan A, Harland KK, Smithline HA, Hou PC, et al. Interim estimates of vaccine effectiveness of Pfizer-BioNTech and Moderna COVID19 vaccines among health care personnel-33 US Sites, January-March 2021. MMWR Morb Mortal Wkly Rep. 2021;70(20):753-8. https://doi.org/ 10.15585/mmwr.mm7020e2.

42. Sheikh A, McMenamin J, Taylor B, Robertson C. SARS-CoV-2 Delta VOC in Scotland: demographics, risk of hospital admission, and vaccine effectiveness. Lancet. 2021;397(10293):2461-2. https://doi.org/10.1016/ s0140-6736(21)01358-1.

43. Shrotri M, Krutikov M, Palmer T, Giddings R, Azmi B, Subbarao S, Fuller C, Irwin-Singer A, Davies D, Tut G, et al. Vaccine effectiveness of the first dose of ChAdOx $1 \mathrm{nCoV}-19$ and BNT162b2 against SARS-CoV-2 infection in residents of long-term care facilities in England (VIVALDI): a prospective cohort study. Lancet Infect Dis. 2021. https://doi.org/10. 1016/s1473-3099(21)00289-9.

44. Skowronski DM, Setayeshgar S, Zou M, Prystajecky N, Tyson JR, Galanis E, Naus M, Patrick DM, Sbihi H, El Adam S, et al. Single-dose mRNA vaccine effectiveness against SARS-CoV-2, including Alpha and Gamma variants: a test-negative design in adults 70 years and older in British Columbia,Canada. Clin Infect Dis. 2021. https://doi.org/10.1093/cid/ ciab616.

45. Swift MD, Breeher LE, Tande AJ, Tommaso CP, Hainy CM, Chu H, Murad $\mathrm{MH}$, Berbari EF, Virk A. Effectiveness of mRNA COVID-19 vaccines against SARS-CoV-2 infection in a cohort of healthcare personnel. Clin Infect Dis. 2021. https://doi.org/10.1093/cid/ciab361.

46. Thompson MG, Burgess JL, Naleway AL, Tyner H, Yoon SK, Meece J, Olsho LEW, Caban-Martinez AJ, Fowlkes AL, Lutrick K, et al. Prevention and attenuation of COVID-19 with the BNT162b2 and mRNA-1273 Vaccines. N Engl J Med. 2021. https://doi.org/10.1056/NEJMoa2107058.

47. Vasileiou E, Simpson CR, Shi T, Kerr S, Agrawal U, Akbari A, Bedston $S$, Beggs J, Bradley D, Chuter A, et al. Interim findings from first-dose mass COVID-19 vaccination roll-out and COVID-19 hospital admissions in Scotland: a national prospective cohort study. Lancet. 2021;397(10285):1646-57. https://doi.org/10.1016/s0140-6736(21) 00677-2.

48. Williams C, Al-Bargash D, Macalintal C, Stuart R, Seth A, Latham J, Gitterman L, Fedsin S, Godoy M, Kozak R, et al. COVID-19 outbreak associated with a SARS-CoV-2 P.1 lineage in a long-term care home after implementation of a vaccination program-Ontario, April-May 2021. Clin Infect Dis. 2021. https://doi.org/10.1093/cid/ciab617.

49. Alhazmi A, Alamer E, Daws D, Hakami M, Darraj M, Abdelwahab S, Maghfuri A, Algaissi A. Evaluation of side effects associated with COVID19 vaccines in Saudi Arabia. Vaccines (Basel). 2021. https://doi.org/10. 3390/vaccines9060674.

50. Andrzejczak-Grządko S, Czudy Z, Donderska M. Side effects after COVID-19 vaccinations among residents of Poland. Eur Rev Med Pharmacol Sci. 2021;25(12):4418-21. https://doi.org/10.26355/eurrev_ 202106_26153.

51. Baldolli A, Michon J, Appia F, Galimard C, Verdon R, Parienti JJ. Tolerance of BNT162b2 mRNA COVI-19 vaccine in patients with a medical history of COVID-19 disease: a case control study. Vaccine. 2021;39(32):4410-3. https://doi.org/10.1016/j.vaccine.2021.06.054.

52. Cherian S, Paul A, Ahmed S, Alias B, Manoj M, Santhosh AK, Varghese DR, Krishnan N, Shenoy P. Safety of the ChAdOx1 nCoV-19 and the BBV152 vaccines in 724 patients with rheumatic diseases: a postvaccination cross-sectional survey. Rheumatol Int. 2021;41(8):1441-5. https://doi.org/10.1007/s00296-021-04917-0.

53. Chevallier P, Coste-Burel M, Le Bourgeois A, Peterlin P, Garnier A, Béné MC, Imbert BM, Drumel T, Le Gouill S, Moreau P, et al. Safety and immunogenicity of a first dose of SARS-CoV-2 mRNA vaccine in allogeneic hematopoietic stem-cells recipients. EJHaem. 2021. https://doi.org/10. 1002/jha2.242.

54. Connolly CM, Ruddy JA, Boyarsky BJ, Avery RK, Werbel WA, Segev DL, Garonzik-Wang J, Paik JJ. Safety of the first dose of mRNA SARS-CoV-2 vaccines in patients with rheumatic and musculoskeletal diseases. Ann Rheum Dis. 2021. https://doi.org/10.1136/annrheumdis-2021-220231.

55. Furer V, Eviatar T, Zisman D, Peleg H, Paran D, Levartovsky D, Zisapel M, Elalouf O, Kaufman I, Meidan R, et al. Immunogenicity and safety of the BNT162b2 mRNA COVID-19 vaccine in adult patients with autoimmune inflammatory rheumatic diseases and in the general population: a multicentre study. Ann Rheum Dis. 2021. https://doi.org/10.1136/annrh eumdis-2021-220647.

56. Gee J, Marquez P, Su J, Calvert GM, Liu R, Myers T, Nair N, Martin S, Clark T, Markowitz $L$, et al. First month of COVID-19 vaccine safety monitoring-United States, December 14, 2020-January 13, 2021. MMWR Morb Mortal Wkly Rep. 2021;70(8):283-8. https://doi.org/10.15585/ mmwr.mm7008e3.

57. Hashimoto T, Ozaki A, Bhandari D, Sawano T, Sah R, Tanimoto T. High anaphylaxis rates following vaccination with the Pfizer BNT162b2 mRNA vaccine against COVID-19 in Japanese health care workers; a secondary analysis of initial post-approval safety data. J Travel Med. 2021. https://doi.org/10.1093/jtm/taab090.

58. Lv G, Yuan J, Xiong X, Li M. Mortality rate and characteristics of deaths following COVID-19 vaccination. Front Med (Lausanne). 2021;8: 670370. https://doi.org/10.3389/fmed.2021.670370.

59. McMurry R, Lenehan P, Awasthi S, Silvert E, Puranik A, Pawlowski C, Venkatakrishnan AJ, Anand P, Agarwal V, O'Horo JC, et al. Real-time analysis of a mass vaccination effort confirms the safety of FDA-authorized mRNA COVID-19 vaccines. Med (N Y). 2021. https://doi.org/10.1016/j. medi.2021.06.006.

60. Monin L, Laing AG, Muñoz-Ruiz M, McKenzie DR, Del Molino Del Barrio I, Alaguthurai T, Domingo-Vila C, Hayday TS, Graham C, Seow J, et al. Safety and immunogenicity of one versus two doses of the COVID-19 vaccine BNT162b2 for patients with cancer: interim analysis of a prospective observational study. Lancet Oncol. 2021;22(6):765-78. https:// doi.org/10.1016/s1470-2045(21)00213-8.

61. Pagotto V, Ferloni A, Mercedes Soriano M, Díaz M, Braguinsky Golde N, González MI, Asprea V, Staneloni MI, Zingoni P, Vidal G, et al. Active monitoring of early safety of Sputnik $V$ vaccine in Buenos Aires, Argentina. MediClna (B Aires). 2021;81(3):408-14.

62. Peled Y, Ram E, Lavee J, Sternik L, Segev A, Wieder-Finesod A, Mandelboim M, Indenbaum V, Levy I, Raanani E, et al. BNT162b2 vaccination in heart transplant recipients: Clinical experience and antibody response. J Heart Lung Transplant. 2021. https://doi.org/10.1016/j.healun.2021.04. 003.

63. Quiroga B, Sánchez-Álvarez E, Goicoechea M, de Sequera P. COVID-19 vaccination among Spanish nephrologists: acceptance and side effects. J Healthc Qual Res. 2021. https://doi.org/10.1016/j.jhqr.2021.05.002. 
64. Ram R, Hagin D, Kikozashvilli N, Freund T, Amit O, Bar-On Y, Beyar-Katz $\mathrm{O}$, Shefer G, Moshiashvili MM, Karni C, et al. Safety and immunogenicity of the BNT162b2 mRNA COVID-19 vaccine in patients after allogeneic HCT or CD19-based CART therapy_-a single center prospective cohort study. Transplant Cell Ther. 2021. https://doi.org/10.1016/j.jtct.2021.06. 024.

65. Revon-Riviere G, Ninove L, Min V, Rome A, Coze C, Verschuur A, de Lamballerie X, André N. The BNT162b2 mRNA COVID-19 vaccine in adolescents and young adults with cancer: a monocentric experience. Eur J Cancer. 2021;154:30-4. https://doi.org/10.1016/j.ejca.2021.06.002.

66. Riad A, Pokorná A, Mekhemar M, Conrad J, Klugarová J, Koščík M, Klugar M, Attia S. Safety of ChAdOx1 nCoV-19 vaccine: independent evidence from two EU states. Vaccines (Basel). 2021. https://doi.org/10.3390/vacci nes 9060673.

67. Riad A, Sağıroğlu D, Üstün B, Pokorná A, Klugarová J, Attia S, Klugar M. Prevalence and risk factors of CoronaVac Side effects: an independent cross-sectional study among healthcare workers in Turkey. J Clin Med. 2021. https://doi.org/10.3390/jcm10122629.

68. Rosman Y, Lavi N, Meir-Shafrir K, Lachover-Roth I, Cohen-Engler A, Mekori YA, Confino-Cohen R. Safety of BNT162b2 mRNA COVID-19 vaccine in patients with mast cell disorders. J Allergy Clin Immunol Pract. 2021. https://doi.org/10.1016/j.jaip.2021.06.032.

69. Signorelli C, Odone A, Gianfredi V, Capraro M, Kacerik E, Chiecca G, Scardoni A, Minerva M, Mantecca R, Musarò P, et al. Application of the "immunization islands" model to improve quality, efficiency and safety of a COVID-19 mass vaccination site. Ann Ig. 2021;33(5):499-512. https://doi.org/10.7416/ai.2021.2456.

70. Vallée A, Chan-Hew-Wai A, Bonan B, Lesprit P, Parquin F, Catherinot É, Choucair J, Billard D, Amiel-Taieb C, Camps Ė, et al. Oxford-AstraZeneca COVID-19 vaccine: need of a reasoned and effective vaccine campaign. Public Health. 2021;196:135-7. https://doi.org/10.1016/j.puhe.2021.05. 030.

71. Wang J, Hou Z, Liu J, Gu Y, Wu Y, Chen Z, Ji J, Diao S, Qiu Y, Zou S, et al. Safety and immunogenicity of COVID-19 vaccination in patients with non-alcoholic fatty liver disease (CHESS2101): a multicenter study. J Hepatol. 2021. https://doi.org/10.1016/j.jhep.2021.04.026.

72. Zhang MX, Zhang TT, Shi GF, Cheng FM, Zheng YM, Tung TH, Chen HX. Safety of an inactivated SARS-CoV-2 vaccine among healthcare workers in China. Expert Rev Vaccines. 2021. https://doi.org/10.1080/14760584. 2021.1925112.

73. Shay DK, Gee J, Su JR, Myers TR, Marquez P, Liu R, Zhang B, Licata C, Clark TA, Shimabukuro TT. Safety monitoring of the Janssen (Johnson \& Johnson) COVID-19 Vaccine-United States, March-April 2021. MMWR Morb Mortal Wkly Rep. 2021;70(18):680-4. https://doi.org/10.15585/ mmwr.mm7018e2.

74. Prevention CCfDCa. Information analysis of COVID-19 vaccine adverse reaction monitoring in China. 2021-5-28. http://www.chinacdc.cn/jkzt/ ymyjz/ymyjjz_6758/202105/t20210528_230908.html. Accessed 20 Aug 2021

75. Kow CS, Hasan SS. Real-world effectiveness of BNT162b2 mRNA vaccine: a meta-analysis of large observational studies. Inflammopharmacology. 2021;29(4):1075-90. https://doi.org/10.1007/ s10787-021-00839-2.

76. Angyal A, Longet S, Moore S, Payne RP, Harding A et al. T-Cell and Antibody Responses to First BNT162b2 Vaccine Dose in Previously SARS-CoV-2-Infected and Infection-Naive UK Healthcare Workers: A Multicentre, Prospective, Observational Cohort Study. Available at SSRN: https://ssrn.com/abstract=3820576 or https://doi.org/10.2139/ssrn. 3820576. Accessed 20 Aug 2021

77. Pimenta D, Yates C, Pagel C, Gurdasani D. Delaying the second dose of covid-19 vaccines. BMJ. 2021;372: n710. https://doi.org/10.1136/bmj. n710.

78. Tauh T, Mozel M, Meyler P, Lee SM. An updated look at the 16-week window between doses of vaccines in BC for COVID-19. BC Med J. 2021;63(3):102-3.

79. Kadire SR, Wachter RM, Lurie N. Delayed second dose versus standard regimen for COVID-19 vaccination. N Engl J Med. 2021;384(9): e28. https://doi.org/10.1056/NEJMclde2101987.

80. Bergwerk M, Gonen T, Lustig Y, Amit S, Lipsitch M, Cohen C, Mandelboim M, Gal Levin E, Rubin C, Indenbaum V, et al. COVID-19 breakthrough infections in vaccinated health care workers. N Engl J Med. 2021. https://doi.org/10.1056/NEJMoa2109072.

81. Truong TT, Ryutov A, Pandey U, Yee R, Goldberg L, Bhojwani D, AguayoHiraldo P, Pinsky BA, Pekosz A, Shen L, et al. Persistent SARS-CoV-2 infection and increasing viral variants in children and young adults with impaired humoral immunity. medRxiv. 2021. https://doi.org/10.1101/ 2021.02.27.21252099.

82. Choi B, Choudhary MC, Regan J, Sparks JA, Padera RF, Qiu X, Solomon $\mathrm{IH}, \mathrm{Kuo} \mathrm{HH}$, Boucau J, Bowman K, et al. Persistence and evolution of SARS-CoV-2 in an Immunocompromised Host. N Engl I Med. 2020;383(23):2291-3. https://doi.org/10.1056/NEJMc2031364.

83. Corey L, Beyrer C, Cohen MS, Michael NL, Bedford T, Rolland M. SARSCoV-2 variants in patients with immunosuppression. N Engl J Med. 2021;385(6):562-6. https://doi.org/10.1056/NEJMsb2104756.

84. Bar-On YM, Goldberg Y, Mandel M, Bodenheimer O, Freedman L, Kalkstein N, Mizrahi B, Alroy-Preis S, Ash N, Milo R, et al. Protection of BNT162b2 vaccine booster against Covid-19 in Israel. N Engl I Med. 2021:385(15):1393-400. https://doi.org/10.1056/NEJMoa2114255.

85. Hause AM, Baggs J, Gee J, Marquez P, Myers TR, Shimabukuro TT, Shay DK. Safety monitoring of an additional dose of COVID-19 vaccineUnited States, August 12-September 19, 2021. MMWR Morb Mortal Wkly Rep. 2021;70(39):1379-84. https://doi.org/10.15585/mmwr. mm7039e4.

86. Furlow B. Immunocompromised patients in the USA and UK should receive third dose of COVID-19 vaccine. Lancet Rheumatol. 2021. https://doi.org/10.1016/s2665-9913(21)00313-1.

87. Flaxman A, Marchevsky NG, Jenkin D, Aboagye J, Aley PK, Angus B, Belij-Rammerstorfer S, Bibi S, Bittaye M, Cappuccini F, et al. Reactogenicity and immunogenicity after a late second dose or a third dose of ChAdOx1 nCoV-19 in the UK: a substudy of two randomised controlled trials (COV001 and COV002). Lancet. 2021;398(10304):981-90. https:// doi.org/10.1016/s0140-6736(21)01699-8.

88. Peled Y, Ram E, Lavee J, Segev A, Matezki S, Wieder-Finesod A, Halperin R, Mandelboim M, Indenbaum V, Levy I, et al. Third dose of the BNT162b2 vaccine in heart transplant recipients: immunogenicity and clinical experience. J Heart Lung Transplant. 2021. https://doi.org/10. 1016/j.healun.2021.08.010.

89. WHO. WHO press conference on coronavirus disease (COVID-19) -4 August 2021. 2021. https://www.who.int/multi-media/details/whopress-conference-on-coronavirus-disease-(covid-19)---4-august-2021. Accessed 20 Aug 2021.

90. Cascella M, Rajnik M, Aleem A, Dulebohn SC, Di Napoli R. Features, evaluation, and treatment of coronavirus (COVID-19). In: StatPearls. edn. Treasure Island (FL): StatPearls Publishing Copyright @ 2021, StatPearls Publishing LLC.; 2021.

91. Goshen-Lago T, Waldhorn I, Holland R, Szwarcwort-Cohen M, ReinerBenaim A, Shachor-Meyouhas Y, Hussein K, Fahoum L, Baruch M, Peer $\mathrm{A}$, et al. Serologic status and toxic effects of the SARS-CoV-2 BNT162b2 vaccine in patients undergoing treatment for cancer. JAMA Oncol. 2021. https://doi.org/10.1001/jamaoncol.2021.2675.

92. Ou MT, Boyarsky BJ, Motter JD, Greenberg RS, Teles AT, Ruddy JA, Krach MR, Jain VS, Werbel WA, Avery RK, et al. Safety and reactogenicity of 2 doses of SARS-CoV-2 vaccination in solid organ transplant recipients. Transplantation. 2021. https://doi.org/10.1097/tp.0000000000003780.

93. Bookstein Peretz S, Regev N, Novick L, Nachshol M, Goffer E, Ben-David A, Asraf K, Doolman R, Sapir E, Regev Yochay G, et al. Short-term outcome of pregnant women vaccinated by BNT162b2 mRNA COVID-19 vaccine. Ultrasound Obstet Gynecol. 2021. https://doi.org/10.1002/uog. 23729.

94. Shimabukuro TT, Kim SY, Myers TR, Moro PL, Oduyebo T, Panagiotakopoulos L, Marquez PL, Olson CK, Liu R, Chang KT, et al. Preliminary findings of mRNA COVID-19 vaccine safety in pregnant persons. N Engl J Med. 2021;384(24):2273-82. https://doi.org/10.1056/NEJMoa2104983.

95. Peled Y, Ram E, Lavee J, Sternik L, Segev A, Wieder-Finesod A, Mandelboim M, Indenbaum V, Levy I, Raanani E, et al. BNT162b2 vaccination in heart transplant recipients: clinical experience and antibody response. J Heart Lung Transplant. 2021;40(8):759-62. https://doi.org/10.1016/j. healun.2021.04.003.

96. Thomas SJ, Moreira ED Jr, Kitchin N, Absalon J, Gurtman A, Lockhart S, Perez JL, Pérez Marc G, Polack FP, Zerbini C, et al. Safety and efficacy of 
the BNT162b2 mRNA COVID-19 vaccine through 6 months. N Engl J Med. 2021. https://doi.org/10.1056/NEJMoa2110345.

97. Falsey AR, Sobieszczyk ME, Hirsch I, Sproule S, Robb ML, Corey L, Neuzil KM, Hahn W, Hunt J, Mulligan MJ, et al. Phase 3 safety and efficacy of AZD1222 (ChAdOx1 nCoV-19) COVID-19 vaccine. N Engl J Med. 2021. https://doi.org/10.1056/NEJMoa2105290.

98. El Sahly HM, Baden LR, Essink B, Doblecki-Lewis S, Martin JM, Anderson EJ, Campbell TB, Clark J, Jackson LA, Fichtenbaum CJ, et al. Efficacy of the mRNA-1273 SARS-CoV-2 vaccine at completion of blinded phase. N Engl J Med. 2021. https://doi.org/10.1056/NEJMoa2113017.

99. Tanriover MD, Doğanay HL, Akova M, Güner HR, Azap A, Akhan S, Köse Ş, Erdinç F, Akalın EH, Tabak ÖF, et al. Efficacy and safety of an inactivated whole-virion SARS-CoV-2 vaccine (CoronaVac): interim results of a double-blind, randomised, placebo-controlled, phase 3 trial in Turkey. Lancet. 2021;398(10296):213-22. https://doi.org/10.1016/ s0140-6736(21)01429-x.

100. Kumar S, Saurabh MK, Maharshi V. Efficacy and safety of potential vaccine candidates against coronavirus disease 2019: a systematic review. J Adv Pharm Technol Res. 2021;12(3):215-21. https://doi.org/10.4103/ japtr.JAPTR_229_20.

101. Burgos-Salcedo J. A rational strategy to support approved COVID-19 vaccines prioritization. Hum Vaccin Immunother. 2021;17(10):3474-7. https://doi.org/10.1080/21645515.2021.1922060
Ready to submit your research? Choose BMC and benefit from:

- fast, convenient online submission

- thorough peer review by experienced researchers in your field

- rapid publication on acceptance

- support for research data, including large and complex data types

- gold Open Access which fosters wider collaboration and increased citations

- maximum visibility for your research: over $100 \mathrm{M}$ website views per year

At BMC, research is always in progress.

Learn more biomedcentral.com/submissions 